\title{
Complications that may Occur in those with Spinal Cord Injuries who Participate in Sport
}

\author{
Richard Nilsen, M.D., Paal Nygaard, M.D.and Per Gunnar Bjørholt, M.D.
} Beitostolen Helsesportsenter, 2953 Beitostolen, Norway.

\section{Summary}

The purpose of this study was to determine the risk of developing complications in paraplegics taking part in sport. It is a retrospective study of patients with complete spinal cord injury at the spinal level of C7-cauda equina/conus injury, and consists of 61 patients admitted to the Beitostolen Healthsportcenter, Norway.

All of them had achieved satisfactory bladder/bowel function. The wheelchair dépendents were all skilled in the use of the wheelchair. They participated in a training programme with an average duration of 25 days. Different activities were tried, such as weight-lifting, pulking, swimming, volleyball, calisthenics in a group, horseback-riding, archery, tabletennis, canoeing, totalling 11955 training hours.

During the training period the following complications were observed: urinary tract infections, pressure sores, and sprains and strains. There were 30 complications, most of them only of minor type.

The incidence of complications, expressed as number of complications/1000 training-hours was, for urinary tract infections-0,50, pressure sores 0,42, sprains/ strains 1,33, others 0,25 : in all 2,51.

Sprains and strains were the most common complications, accounting for about 55 per cent of the total, all of which were successfully treated before discharge. Sport activities are an important part of the rehabilitation of the spinal cord injured and the risk of serious complications appears to be low.

Key words: Spinal cord injury; Sport; Complications.

\section{Introduction}

Physical training is an important part of the rehabilitation of the spinal cord injured (Guttmann, 1976). Muscle strength and endurance in the upper, healthy part of the body are crucial factors in mastering ambulation and other ADL-activities. Disabled athletes have reached outstanding levels of performance, both in endurance activities like marathon racing, and muscle 
strength activities such as weightlifting. The experience of these enthusiasts are applied in the rehabilitation field and have created new approaches, techniques and facilities. Outstanding performers, disabled or not, will always run the risk of injury as they stress tissue tolerance up to its maximum during training and competitions. The risk of injury during training for the disabled sportsman is unknown to us. The purpose of this study is therefore to estimate the risk of complications for the spinal cord injured during physical training and to register the kind of complications that occur.

Beitostølen Helsesportsenter is a rehabilitation hospital specially designed for the training and teaching sports for the disabled. Different kinds of disabled are admitted in order to improve their physical fitness and to practice different sports. Hopefully this will make their training at home easier in the future.

\section{Material}

From $1 / 1 / 73$ to $31 / 12 / 82,61$ patients with complete spinal cord traumatic lesion were admitted to the hospital. Several had more than one admission, so

Table 1 Admissions

\begin{tabular}{lcl}
\hline Female & Male & Total \\
\hline 20 & 109 & 129 \\
$15.5 \%$ & $84.5 \%$ & $100 \%$ \\
\hline
\end{tabular}

Table 2 Level of injury

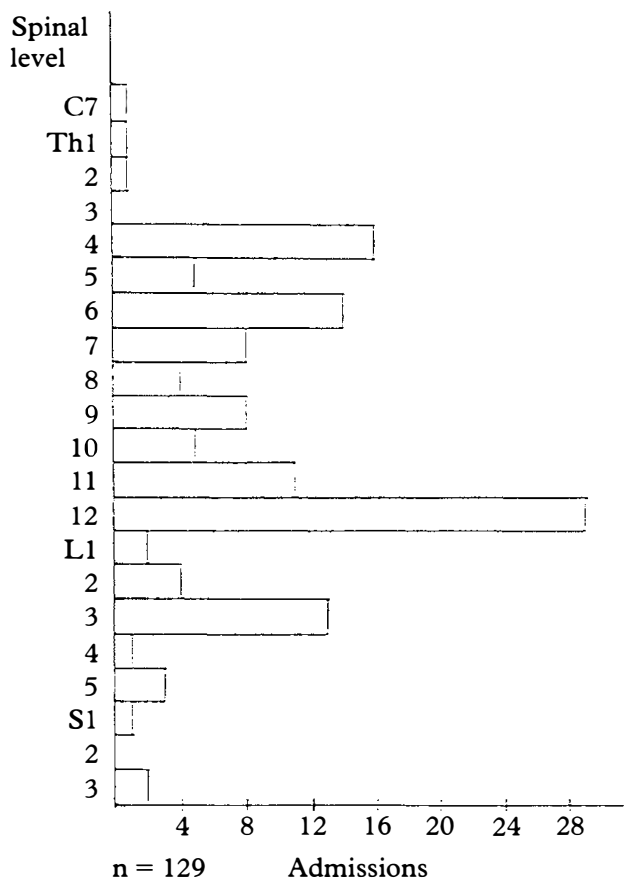


that the total number of admissions was 129. The mean duration of the hospital stay was 25 days (7-124). Twenty females were admitted $(15 \cdot 5 \%)$ and 109 males $(84.5 \%$ ) (Table 1$)$. The years of disability varied from half a year to 36 years, (mean 9.5 years). The level of the spinal injury varied from $\mathrm{C} 7$ to cauda equina/ conus injury. Most injuries were at the thoracic level as shown in Table 2. Of the total number of 61 patients, 47 patients ( 99 admissions) had a traumatic, and 14 patients (30 admissions) a non-traumatic lesion.

Looking at the social status at the time of injury there were 16 schoolchildren, 6 students, 16 manual workers (including sailors and farmers), and

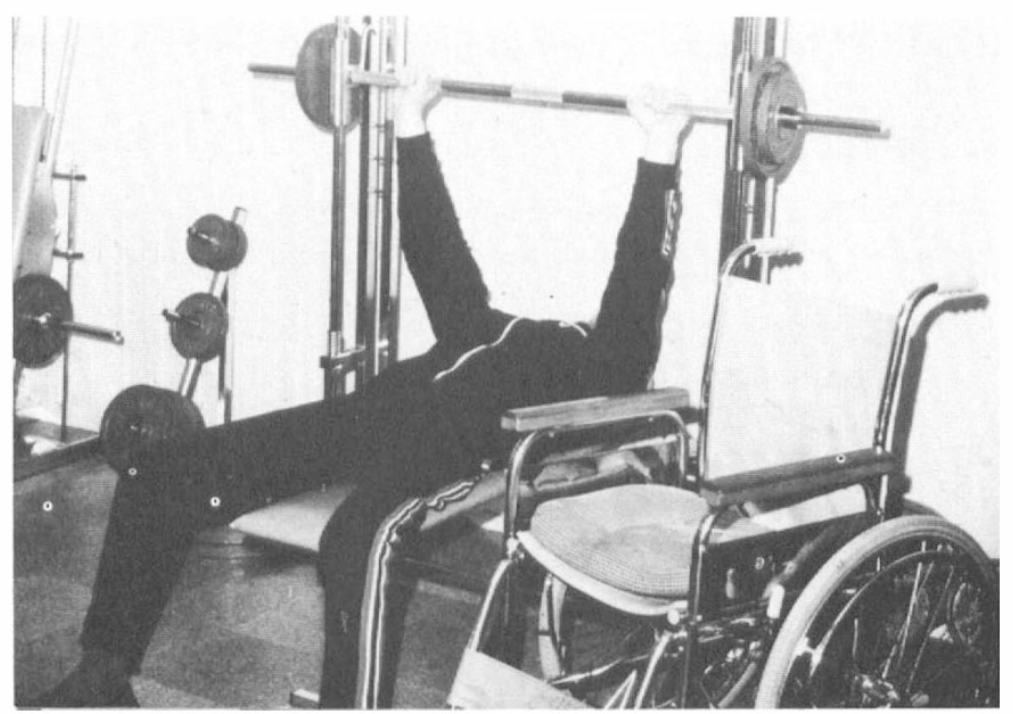

Figure 1. Weightlifting was the most popular frequent used activity in this group.

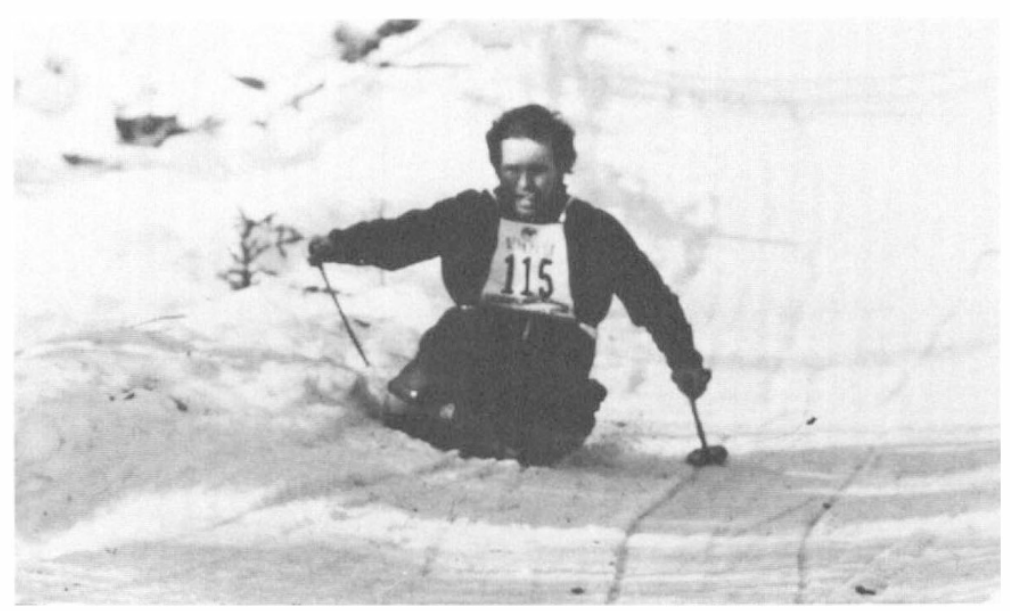

Figure 2. Pulking was the second most popular activity. As pulking only can take place in wintertime, and approximately half of the patients stayed during summertime, far more paraplegics would have been participating in this activity if possible. 
14 office workers. Ten were undetermined. All the patients had achieved satisfactory bladder/bowel function before arrival. The wheelchair dependents were all skilled in the use of a wheelchair. We registered 15 females and 41 males admissions in the summertime, and five females and 68 males admissions in the wintertime. Different sport activities were tried out such as weightlifting ${ }^{\star}$, pulking (Fig. 2) on ice and snow, swimming, volleyball, calisthenics in a group, horseback-riding, archery, tabletennis, canoeing (Table 4 ). The time spent on each activity varied from 30 minutes up to 2-3 hours (for pulkers), averaging about 45 minutes. In all the patients had 3297 training days, 11955 training hours (Table 3). In other words, 3.5 training hours each day, 6 days a week.

Table 3 Training period

\begin{tabular}{lccc}
\hline Patients & Training days & Training hours & Hours/day \\
61 & 3297 & 11955 & 3.63 \\
\hline
\end{tabular}

Table 4 Activities

\begin{tabular}{lrc}
\hline Activity & \multicolumn{2}{c}{ Admissions } \\
\hline Weight-lifting & 102 & $79 \%$ \\
Pulking & 76 & $59 \%$ \\
Swimming & 69 & $53 \%$ \\
Volleyball & 66 & $51 \%$ \\
Callisthenics & 45 & $34 \%$ \\
Horseback-riding & 40 & $31 \%$ \\
Archery & 39 & $30 \%$ \\
Tabletennis & 34 & $26 \%$ \\
Dogsledging & 26 & $20 \%$ \\
Canoeing & 24 & $18 \%$ \\
Others & 32 & $24 \%$ \\
\hline
\end{tabular}

Table 5 Complications

\begin{tabular}{lc}
\hline Pressure-sores & 5 \\
Urinary-tract & \\
$\quad$ infections & 6 \\
Sprains and & 16 \\
$\quad$ strains & 3 \\
Others & 30 \\
Total & \\
\hline $\mathrm{n}=129$ &
\end{tabular}

\section{Methods}

The records of each spinal cord injured patient admitted to hospital during the ten-year periods were carefully examined, the complications were registered and arranged in the following groups (Table 5):

*A pulk is a boat-shaped snow-sledge, and not a boat-shaped ice-sledge. It can however also be used on ice, but the original pulk is an equipment developed for snow-surface. It is used by the laps when driving with reindeers in the northern part of Norway. From the reindeer pulk the equipment for snow-activities for paraplegics has been derived. One sits in a boat-shaped sledge and uses short ski-sticks to push forward. It has been used in Norway by paraplegics for many years, and here we call it pulking. We have seen different names on it, like sledge racing, pulk-ski-ing, sit ski-ing. We feel that the correct name should contain the word pulk, as it is derived from the reindeer equipment used in Norway. 
1. Pressure sores.

2. Urinary tract infections.

3. Sprains and strains.

4. Others.

\section{Results}

Some of the patients had urinary tract infections and pressure sores at the time of admissions. Ten patients had pressure sores; two of these were suspected of developing osteomyelitis and transferred to other hospitals for treatment. The remaining eight participated in the training activities and were free of pressure sores at discharge. Pressure absorbing equipment were used during the training. Nineteen patients had a urinary tract infection on arrival. Of these 14 were cured during their stay. No signs of kidney damage were registered. All of them participated without restrictions.

During the training period 30 patients developed a new complication: Pressure sores five $(17 \%)$, urinary tract infection six $(20 \%)$, strains and sprains 16 $(53 \%)$ and others three $(10 \%)$. In the latter group two of the patients developed increased spasticity and one acquired a fractured tibia. This patient had a marked osteoporosis, and the fracture occurred during passive stretching for spasticity. One of the patients with pressure sores was transferred to another hospital with possible osteomyelitis. The remainder of the patients with pressure sores and urinary tract infection were all successfully treated in this hospital and were symptom free at discharge. In the group with strains and sprains all were treated successfully. With regard to the seasons, there was no striking difference in the incidence of complications. The rate of complications was, as expected, slightly higher for females regarding urinary tract infections. For the other groups the complication rate was almost identical for the two sexes. The incidence rate of complication expressed as number of complications per 1000 training hours was for urinary tract infection 0.50 , pressure sores 0.42 , sprains and strains 1.33 , others 0.25 , in all 2.51 . It is difficult to find a specific factor in the activities causing the complications, especially in relation to pressure sores and urinary tract infections. Sprains and strains usually occurred in the first week in untrained patients starting out too vigorously.

Of the 16 cases of sprains and strains, strains accounted for the majority of the complications. As our study is a retrospective one, the information is based on what is described in the patients' charts. In the shoulder region 12 patients had complications, four were described as tendinitis (bicepstendinitis or suprapinatus-tendinitis), the remaining eight were only described as unspecific pain in the shoulder region. In the elbow and arm, three patients had complications, one was described as epicondylitis, one tendinitis and one as unspecific muscular pain. Lastly one patient was described as having unspecific back pain.

It has been stated that the disabled have a higher risk of developing complications during sport activities (Jackson and Fredrichson, 1979). This does not appear to be the case for the spinal cord injured.

Nilsson and Roaas (1978) report a frequency of 23/1000 playing hours in boys 
playing soccer, and 4/1000 playing hours in girls. Ekstrand and Gillqvist (1982) have found $8 / 1000$ in adult players.

In other contact sports such as lacrosse, the risk of injury is as high as 13/1000 training hours and 443/1000 game hours (Nelson et al., 1981). Accurate injury data from winter sports are difficult to obtain but rough estimates show $10 / 1000$ skier-days in downhill skiing (Ellison, 1972) and 0.5/1000 skierdays in cross country skiing (Garaick, 1971). From our study with a total incidence rate of complications of $2 \cdot 51 / 1000$ training hours it can surely be stated that the risk of injury and other complications are fairly low. Many factors may contribute to this fact: Skilled instructors supervised by medical staff, stressed the importance of mastering technical details, submaximal levels of training, variation of training activities and thus avoidance of uniformity in work. The successful treatment of sprains and strains underline the importance of proper first aid, early diagnosis and treatment in this type of injury. The more serious complications, like pressure sores and urinary tract infections, are rare, but are still to be considered a hazard. Further steps are to be taken to prevent such complications.

Several of the patients in our material already had complications on arrival. This underlines the fact that pressure sores and urinary tract infections do not necessarily relate to physical training. This must not, however, lead us into the mood of 'laissez faire', and precautions should always be taken.

Madorsky and Curtis (1984) have stressed the importance of preventing injury in wheelchair sports. For paraplegics we would like to add a few rules and summarize the prophylactic guidelines to be considered before exercise:

1. Proper hygiene and skin care.

2. Empty the bladder.

3. Careful examination of exposed skin areas, if necessary using a mirror.

4. Pressure-absorbing cushions for the sacrum, the ischial tuberosities and other bony prominences.

5. Proper clothing for the season.

6. Possibilities for fluid intake in hot climate and longlasting sessions.

7. Sufficient warm up, specially in vigorous and new types of activities.

8. If flushing, tachycardia, headache, spasticity and pain of unknown origin occurs, take a day's rest.

\section{Conclusions}

The risk of developing a sports-injury for active spinal cord injured patients appears to be fairly small. The benefits of training are clearly documented and outweighs the small chance of a complication. Consequently, there should be no need to restrain 'healthy' paraplegics from adapted physical activities.

\section{Résumé}

Le dessein de cette étude était d'évaluer le risque de déveloper/les complications chez les paraplegiques participant en sport.

C'est une étude retrospective en patients avec des lésions completement de la épiniére,-_dans la zone de $\mathrm{C}_{7}$-jusqu'a cauda equina/conus,-61 patients hospitalisées a Beitostølen Helsesportsenter en Norvége. 
Tous les patients avaient obtenue une fonction satisfaisante du boyau et de la vessie.

Les patients qui se servantes des fauteuils a roues avaient l'experience de l'usage.

Les patients participaient dans une programme d'exercice qui durait au moyenne de 25 jours. Les activitées differentes étaient essayées,-comme pour example la haltérophilie,_la natation, la volleyballe,-la gymnastique en groupe, l'équitation, tir de l'arc, le tennis de table-pagayer en canot-completement 11955 leçons d'exércices.

Pendant la période d'exercise les complications suivantes étaient observées: L'infection de la voie urinaire, les blessure de la pression,-l'entorse et la foulure.

En tout 30 complications-la pluparts seulements de la catégorie moins grave. La fréquence des complications,-exprimé comme nombre de complications en 1000 leçon d'exercice était,-pour l'infection de la voie urinaire $0 \cdot 50$, - des blessure de la pression $0 \cdot 42$, - de l'entorse et de la foulure$1 \cdot 33$-autres $0 \cdot 25$, - en tout $2 \cdot 51$.

L'entorse et la foulure etaient les complications plus fréquentes-avec $55 \%$ de tous les complications.

Tous étaient traité avant l'exeat. Les activitées du sport est une part importante de la réhabilitation des patients avec les lésions de la epiniére et le risque de complications se montré d'être petit.

\section{Zusammenfassung}

Der Zweck dieses Studium war, den Risiko einer Entwicklung von komplikationen bei paraplegikeren, die in Sportsaktivitäten teilnehmen,-zu bestimmen.

Es ist ein retrospektives Studium von Patienten mit kompletten Schaden im Rückenmark, in einer Höhe von $\mathrm{C}_{7}$ bis zum cauda equina/conus.

Die Gruppe bestand aus 61 Patienten alle im Beitostølen Helsesportsenter, Norwegen, eingeschrieben. All hatten sie eine zufriedenstellende Funktion von Blasen und Darm. Die Patienten, die von Rollstühlgebrauch abhängig waren-hatten alle diese Funktion schon genügend gelernt.

Diese Patienten nahmen alle an einem Aktivitätsprogramm,- das im Durchschnitt eine Dauer von rund 25 Tagen hatte,-teil. Verschiedene Aktivitäten waren hier versucht, wie z.B. Schwimmen, Volleyball, Reiten, Tischtennis, Bogenschiessen, Paddeln,_insgesamt 11955 Lektionen.

In der Zeit mit Aktivitäten wurden die folgenden Komplikationen observiert: Infektion im Harnsystem, Druckwunden, Verstauchungen und Verrenkungen,-insgesamt 30 Komplikationen, die meisten von denen aber nicht so ernsthaft.

Die Häufigkeit von Komplikationen, ausgedrückt als Anzahl Komplikationen pro 1000 Lektionen war, für Infektionen im Harnsystem 0.50, Druckwunden $0 \cdot 42$, Verstauchungen und Verrenkungen 1.33 und andere $0 \cdot 25$. Total $2 \cdot 51$.

Die Verstauchungen und Verrenkungen waren die gewöhnlichsten Komplikationen, mit ungefähr $55 \%$ von den gesamten Komplikationen. Sie waren alle vor dem Ausschreiben des Patienten mit Erfolg behandelt.

Die Sportsaktivitäten sind ein wichtiger Bestandteil in der Rehabilitierung von Patienten mit Schaden im Rückenmark und das Risiko einer Entstehung von Komplikationen scheint. sehr niedrig zu sein.

\section{References}

Ekstrand T, Gillqvist J 1982 The frequency of muscle tightness and injuries in soccer players. American Journal of Sports Medicine 10:75-78.

Ellison A 1972 Skiing injuries. Ciba Clinical symposia. Vol 29, Summit NJ, Ciba Pharmacentical Co.

GaraICK JG 1971 The epidemiology of ski injuries. Minnesota Medicine 54:17-18.

Guttmann L 1976 Textbook of Sport for the Disabled. Sir Ludwig Guttmann, HM \& M Publishers Ltd, Aylesbury, U.K.

JACKSON RW, FREDRICHSON A 1979 Sport for the physically disabled. The 1976 Olympiad (Toronto). American Journal of Sports Medicine 7:293-296.

MADORSKY JGB, CURTIS KA 1984 Wheelchair sports medicine. American Journal of Sports Medicine 12:128-132.

NELSON WE' et al. 1981 Intercollegiate Lacrosse injuries. Physical Sports Medicine 9:86-92.

Nilsson S, RoAas A 1978 Soccer injuries in adolescent. American Journal of Sports Medicine 6:358-361. 